SCJR 16, no. 1 (2021): 1-4

\title{
Daniel G. Hummel \\ Covenant Brothers: Evangelicals, Jews, and U.S.-Israeli Relations
}

(Philadelphia: University of Pennsylvania Press, 2019), hardcover, 317 pp.

\author{
CAITLIN CARENEN
}

carenenc@easternct.edu

Eastern Connecticut State University, Willimantic, CT 06226

In Covenant Brothers: Evangelicals, Jews, and U.S.-Israeli Relations, Daniel Hummel offers readers a new perspective on evangelical-Jewish relations and its impact on U.S-Israeli foreign policy. From the beginning, Hummel suggests that scholarship that focuses on the apocalyptic nature of dispensational premillennialism's attitudes toward Jews and Israel and uses this as a full explanation of Jewishevangelical relations is missing a more subtle, and more theologically profound, understanding of how and why evangelicals eagerly turned toward modern Jews and the State of Israel. Hummel's organization and title come from the two biblical passages that he argues have shaped this relationship more than anything else: Genesis 12:3 (when God said to Abraham "I will bless those who bless you"), and Romans 11 (when Paul informs Gentile Christians that they are but branches grafted onto the Jewish olive tree). From these verses, Hummel argues, evangelicals, acknowledging that Christians and Israel "have a shared root, a shared faith, a shared fate," have adopted a different approach toward Jews and engaged in vigorous support of the state of Israel (5). Hummel then traces the development of "advocacy, organizing, and cooperation" between evangelicals and modern Israel and, in so doing, offers a gentle revision to scholarship that insists evangelicals are only focused on the end of times and on the role Israel plays in this scenario and ignores the mutuality of the evangelical-Israeli relationship and its "covenantal solidarity" (3).

With the olive branch analogy offered in the New Testament book of Romans at the forefront of Hummel's argument, he then organizes the book into three sections: "Roots, 1948-1967," "Shoots, 1967-1976," and "Branches, 1976-2018." Starting with the establishment of Israel in 1948, Hummel argues in "Roots" that the legacy of the Holocaust and Israel's reality forced evangelicals to take seriously the long history of Christian anti-Judaism and the centrality of Israel to modern Jewish identity, and thus to modify approaches to mission accordingly. Evangelicals created a "new language of reconciliation" in their relationship to Jews (21). Using the idea of "witness" to replace "missions," evangelicals largely abandoned 
aggressive attempts to convert Jews to Christianity (in part because the state of Israel vehemently resisted missionizing and because Jews in Israel proved generally uninterested in conversion). Understanding that support of Zionism made the Israeli government less hostile to the presence of missions in Israel, evangelicals quickly adapted their strategy to show "Christianity's inherent Jewishness" (27). They also enthusiastically endorsed Jews' biblical claims to the land. Eager to protect their presence, evangelicals devoted energy to supporting religious freedom in Israel, de-emphasized conversion, and underscored the connection between Judaism and Christianity. The later effort aligned with the Cold War "discovery" of the Judeo-Christian heritage and positioned Israel and the U.S. as the defenders of Judeo-Christian civilization. Through this, evangelicals could emphasize the "covenantal" relationship between Jews and Christians while reiterating biblical authority through support of biblical archaeology (which Hummel points out nicely aligned with Israeli efforts to showcase ancient claims to the land).

In the last chapter of the "Roots" section, Hummel uses a case study of the career of G. Douglas Young (1910-1980) to show how the modern Christian Zionist movement embodied these new trends. Young established the "overtly proIsrael" Institute of Holy Land Studies in Jerusalem to create "an effective fusion of reconciliationist impulses, Judeo-Christian thinking, biblical archaeological knowledge, and Zionism" (60), and in so doing created a foundational organization in the new evangelical approach to Jews and Israel. His Institute presented proZionist perspectives to evangelical tourists and leaders and was therefore supported by the Israeli government. Hummel argues that "By positioning the Institute as a site of cultural exchange and public diplomacy as well as an educational institution, Young bridged interreligious and theological interests with a political agenda," one that encouraged evangelicals to consider what they could do for Israel (67).

In Hummel's second section, "Shoots," he argues that in the wake of the 1967 War, the Israeli government actively sought support for the annexation of Palestinian territories from American evangelicals. Much of the world, and certainly liberal American Protestants, condemned Israeli annexation of east Jerusalem. But evangelicals interpreted Israel's land policies as the fulfillment of God's promise to the Jewish people to live in the Holy Land. The Israeli government understood that evangelical support would help secure friendly U.S.-Israeli relations and bring U.S. aid. American Jewish leaders emphasized the centrality of the land to the notion of Jewish peoplehood, and evangelicals, already primed for this connection, embraced support of the Jewish state post-1967 as evidence of the continued fulfillment of biblical prophecies. American Jewish organizations (particularly the American Jewish Committee) and the Israeli government actively courted the growing evangelical community's support at both the grassroots and leadership levels. Billy Graham, Arnold T. Olson, and W.A. Criswell — all evangelical leaders — responded favorably. All de-emphasized conversion and instead focused on understanding the modern state of Israel, Jewish identification with Israel, and the Jewishness of Christianity (while often ignoring Arab perspectives). This approach broke with evangelical views prior to 1967 and reflected increasing interreligious cooperation between evangelical and Jewish leaders in the U.S. on behalf of Israel. Moreover, 
the active efforts of the Israeli government to garner evangelical support showcased a "new Israeli public diplomacy effort targeting American evangelicals" (96).

This section also shows the extent to which the Israeli government, particularly the Ministry of Tourism, actively sought American evangelical support, through awarding and supporting notable evangelical Israel boosters who developed proZionist tourism in Israel for American evangelicals that emphasized its "sacred landscape" (122). Interestingly, it is in this section that Hummel acknowledges that an uneasy tension existed among evangelicals over whether and how to emphasize prophecy fulfillment (represented by the views of Hal Lindsey) versus the Jewishness of Christianity (represented by the views of Young) in organizing events and Holy Land tourism to evangelicals. Because of this tension, Hummel ultimately concludes that "evangelicals remained deeply divided over the theological meaning of Israel and the political responsibilities owed to ensuring its security" (127). Between 1971 and 1973, cracks in the relationship between Israel, evangelicals, and evangelical-Jewish relations in the U.S. revealed "a string of interreligious disputes and misadventures" that would continue for some years until the cracks were smoothed over, ultimately culminating in effective political mobilization and in creating the modern evangelical Zionist identity (129).

In the final section, "Branches, 1976-2018," Hummel addresses modern evangelical Zionist identity and the ever-closer relationship between Israel and American evangelicals. Prime Minister Menachem Begin and Rev. Jerry Falwell, "the new faces of the U.S.-Israeli relationship and the architects of the Christian Zionist movement" (159), represent this tightening alliance that has produced, over several decades, phenomenally influential lobby groups like John Hagee's Christians United for Israel and made support for Israel a fundamental pillar of the Christian Coalition. Christian Zionists became stanchly pro-Israel even during politically-difficult times (the $1982 \mathrm{War}$ in Lebanon, for example). Hummel argues that this "tectonic" power shift made evangelical support for Israel far more unstable and it ignored the emphasis on interreligious dialogue, biblical archeology, and theological innovations that had characterized evangelical support for Israel during the "Roots" and "Shoots" periods. Now a new kind of prosperity gospel motivates Christian Zionist support: a re-emphasis of Genesis 12:3 as a promise of material and financial blessings on those who donate to far-right Israeli causes (like supporting settler communities in the Occupied Territories and the 2018 Trump decision to move the U.S. embassy to Jerusalem). Hummel argues that this is not a total rejection of earlier interfaith emphasis. He argues instead that this is a "culmination [of efforts begun in 1948] and a transformation of the Christian Zionist movement" (187). Hummel concludes that "Reconciliation highlights the decisive reading of Genesis 12:3 at the center of modern Christian Zionism, and the overriding motif — not of rapture or fire — but of covenant solidarity" (238).

It is in this section that Hummel's argument is somewhat less convincing. I recognize the contribution his work makes to a more subtle understanding of Jewish-evangelical and U.S.-Israeli relations by emphasizing the covenantal nature of 
that relationship and de-emphasizing the sensationalism of premillennial dispensationalism. Yet a peeling back of all of the onion layers seems to still reveal an opportunistic motivation for evangelical support of Israel, particularly in light of the new evangelical prosperity gospel. Despite this, Covenant Brothers offers a great deal to the study of the intersection of religion, politics, and foreign policy by offering a more intimate and nuanced examination of evangelical motivations and organizations. Hummel has mined an impressive collection of primary sources and offers an elegant argument. His prose is clear, direct, and lively, making this book a pleasure to read. 